\title{
Impact of Oil and Gas Activities on Acidity of Rain and Surface Water of Niger Delta, Nigeria: An Environmental and Public Health Review
}

\author{
John Kanayochukwu Nduka',2, Vincent Nwalieji Okafor'1, Isaac Omoche Odiba ${ }^{3}$ \\ ${ }^{1}$ Environmental Chemistry and Toxicology Research Unit, Pure \& Industrial Chemistry Department, Nnamdi Azi- \\ kiwe University, Awka, Nigeria \\ ${ }^{2}$ Department of Chemistry, Federal University, Lafia, Nigeria \\ ${ }^{3}$ Department of Chemistry, Alvan Ikoku Federal College of Education, Owerri, Nigeria \\ Email:johnnduka2000@yahoo.co.uk
}

Received 14 January 2016; accepted 25 March 2016; published 30 March 2016

Copyright (C) 2016 by authors and Scientific Research Publishing Inc.

This work is licensed under the Creative Commons Attribution International License (CC BY). http://creativecommons.org/licenses/by/4.0/

(c) (i) Open Access

\section{Abstract}

Acidic aerosols resulting from gas flaring and refinery operations in the Niger Delta are a serious environmental and public health concern. Several thousand tons of flue gas components (dust particles, $\mathrm{SO}_{\mathrm{x}}, \mathrm{CO}$ and $\mathrm{NO}_{\mathrm{x}}$ ) are released into the atmosphere by flaring billions of cubic meters of natural gas and refining and volatilizing the spilt oil. Heat waves are generated by flaring travels several meters away from flare points, destroying crops, farm lands, exotic species that are hunters delight while causing extinction of fragile soil flora and fuana. The occurrence of acid rain in the region implies that the natural receptors of the area are the final recipient of land and atmospheric pollutants. In effect, the water needs and public health of the populace are greatly impeded. Nitric and sulphuric acids are regarded as the sole contributors of nitrate and sulphate in precipitation influenced by combusted hydrocarbons: fine nitrate aerosols that dissolve in rain water are conversion products of $\mathrm{NO}_{2}$ that arise from flaring, power plants and motor vehicles. Scientific evidence has shown that rain water and surface water quality in the Niger Delta can accentuate the poor health burden, and may be perpetuated through generations unborn. Diagnostic health risk assessment has revealed that drinking nitrate contaminated water may be associated with spontaneous miscarriage, ectopic pregnancy, adult malignant lymphomas, soft tissues sarcomas, cancers and lesions with added health burden associated with heavy metals and other ions. All these pose public health emergency and may significantly entrench health risk for generations to come. Therefore, this manuscript is intended to close certain gaps that were not covered by toxicological information and available data on environmental and food contamination and human internal ex- 
posure: it will serve as a continuous reminder and a useful guide to public health policy makers, workers and community based physicians.

\section{Keywords}

Precursor Gases, Acid Precipitation, Natural Receptors, Gas Flaring, Environmental Pollution, Public Health, Niger Delta, Nigeria

\section{Introduction}

The world is presently tackling three critical crises, namely: environmental pollution, fresh water demand and new energy sources [1] [2], although the three are interconnected, energy and new energy sources are the most potent factors in the world's economy and politics. Energy determines the health of any nation's economy, the issue of energy, fuel and power generation propels the economy of the developed world. Other issues such as sustainable development, standard of living, clean and healthy environment etc., revolve around adequate fuel and energy supply system. Petroleum is the most important energy source worldwide; it is a complex mixture of hydrocarbon compounds with minor quantities of nitrogen, oxygen and sulphur-containing compounds as well as trace amounts of metal-containing compounds [3]. Many countries are heavily dependent on petrol-based resources as their main source of electricity and transportation fuel, therefore global oil and gas demand increases daily, but petroleum is not used in its raw state, various processing steps are required to convert it from raw state to products that are usable in modern society [4]. The resultant effect of these processes is environmental pollution, prominent in oil and gas industry is corrosion and acidic precipitation. A variety of ecological, chemical, physical and human factors determine whether an ecosystem may be disposed to acidic deposition or not. It is a term used to describe several ways that acids and their salts fall from the atmosphere. The large and increasing number of industries and rapidly diversification of technologies are proposed to lead to greater emission of atmospheric pollutants. The health effects of air pollution exposure have become an important area of increasing concern in the past 40 years. Voluminous evidence has demonstrated that there are serious health consequences to community air pollution and that these consequences are not evenly spread among population [5]. Ambient air pollutants also vary in nature (e.g. $\mathrm{CO}, \mathrm{SO}_{2}$ and particulate matter) and possible health effects. Exposure to ambient levels of CO may result in the formation of carboxyhemoglobin while inhaled particles, in contrast, have been reported to increase blood viscosity, these two effects may interfere with oxygen delivery to the tissues [6]. One of direct effects of atmospheric pollution is acidic precipitation, a phenomenon that is receiving global interest because it affects terrestrial and aquatic ecosystems with attendant public health implication. Acid rain has been reported in Nigeria's Niger Delta region [7] [8]. Oil exploration and exploitation have been dominant activities in the area for more than 40 years. Crude and refined oil spillages, gas flares and industrial effluents, automobile emissions as a result of affluence from oil and gas economy etc. have impacted negatively on the air, arable land and the aquatic ecosystem, and there is serious pollutant-atmosphere interaction [8]. The US Department of Energy estimates that since 1960, there have been more than four thousand ( $>4000)$ oil spills discharging several million barrels of crude oil into the ponds, ditches, creeks, beaches, streams and rivers of the Niger Delta [7]. Large volumes of the spills are volatile hydrocarbons that escape into the atmosphere within seconds to undergo chemical oxidation. In this review, the exposure scenario and the risks due to continued usage of natural receptors, contacts and episodes of acidic precipitation are brought to the fore and to draw the attention of policy makers because the most evident health-related issues are related to occupational and direct local exposure and are mostly evident among rural, poor and uneducated populace of the region.

\section{The Niger Delta Region}

Nigeria's Niger Delta is located on the margins of Gulf of Guinea in the equatorial West Africa on latitudes $3^{\circ}$ and $6^{\circ}$ North and longitudes $5^{\circ}$ and $8^{\circ}$. It is one of the most prominent basins in West Africa and actually the largest delta in Africa. It includes the Imo River and Cross River deltas and extends into the continental margins of Cameroun and Equatorial Guinea [9]. The complex is located in the Atlantic coast of Southern Nigeria where River Niger divides into numerous tributaries). 
The area is the second largest delta in the world spanning a coastline of about $450 \mathrm{~km}$ foreclosing at Imo River [10]. It is the largest wetland in Africa, spanning over 20,000 square kilometers and among the three (3) largest in the world. It ranks amongst the world's most prolific petroleum tertiary delta that together account for about $5 \%$ of the world's oil and gas reserves. The structural features and petro physical properties account for the hydrocarbon occurrence. Three (3) major formations exist in the area, namely Benin, Agbada and Akata. The Benin formation is mostly continental units of sand mixed with gravel and restricted clays, sequence of sandstone/shale exist in Agbada formation, which is the oil-reservoir (i.e. oil and gas in the area mainly occur in sandstone reservoirs throughout the Agbada formation). The Akata formation is regarded as over pressured shale [11]. Delta sediments are reported to be layered in structure, but the layers of alternating sands, silts and clays may not be homogenous [12].

\section{The Niger Delta Natural Receptors}

Viewing the map of Nigeria, one observes that nature naturally endowed the Niger Delta area with enormous water resources. A delta is a geographical feature formed when a River (in this case River Niger) diversifies into numerous streams that sometimes inter-connect into an intricate web of Rivers, lagoons, swamps and wetland. The above features are in abundant in the Niger Delta and are of immense economic importance to the nation. They are the tributaries of River Niger. It is estimated that about $2400 \mathrm{sq} \cdot \mathrm{km}$ of the area consist of rivers, creeks and estuaries while stagnant swamp covers about $8600 \mathrm{sq} \cdot \mathrm{km}$. Its mangrove swamp of $1900 \mathrm{sq} \cdot \mathrm{km}$ is the largest in Africa [10]. The area falls within the tropical rain forest zone of Nigeria, given rise to highly diverse ecosystem that is supportive to several species of terrestrial and aquatic flora, fauna and human life.

Four (4) zones exist in the area: coastal inland, mangrove swamp, fresh water and lowland rain forest, the dominant fresh water aquifer is found in the Benin formation, though there is shallow aquifer. Accessible fresh water could occur in the first 100 - $200 \mathrm{~m}$ [13]. Water levels can be located at less than $1 \mathrm{~m}$ near the coast to more than $10 \mathrm{~m}$ inland [14]. The whole region receives more than $5000 \mathrm{~mm}$ of rainfall annually, even dry season receives occasional rainfall [15], so there is enough water to recharge both underground and surface water (natural receptors) all year round. Evapo-transpiration is estimated at over $1000 \mathrm{~m}$ per year and almost all the surface water overflow their banks every year due to flooding from rain water and ocean surge, this results in diverse interaction among the surface water bodies (natural receptors) Types of natural receptors in the area include rivulets, ponds, ditches, salt marshes, mangrove swamps, lakes, Rivers and River meanders with its network of tributaries and creeks which empties into the sea. The drainage pattern is dendritic with tributaries branching without any preferred orientation. The rivers are perennial and tide influenced. There is fresh water/salt water mixture, resulting in brackish environment at the bank of the rivers and adjoining creeks [16]. The environment that is worst affected in the Niger delta region of Nigeria needs serious and immediate clean-up in case of oil spill, they include:

1) Sheltered shoreline: Shores like salt marsh, mangroves and mud shores, the oil can cause an enormous damage. These sorts of shores are often very sensitive to oil pollution. They are feeding areas of birds when the tides are out, and for fish when the tides are in, they have very low self-cleaning potential, as the oil can have very long term impacts in worst case scenarios in sheltered areas [17].

2) Sandy Beaches: Pure sandy beaches are also exposed to strong wave action or currents and are not very sensitive because the animal life is limited. Self-cleaning potential is also high.

3) Mangroves: Mangroves like salt marshes are usually found in every sheltered area and have very low self cleaning potential. The mangrove plants have breathing roots called pneumatophores and are usually left alone because physical clean-up would certainly do more damage [17].

4) Pebbles and Cobbles: They have grain size from $2 \mathrm{~mm}$ to $250 \mathrm{~mm}$. This type of shoreline is the most difficult to clean satisfactorily. Oil penetration increases with increasing stone size, because much of the oil will have penetrated into spaces between the stones, deep into the beach. Surface stones are cleaned quickly by abrasion whereas buried oil may persist for a long time.

5) Exposed shore line: The exposed communities of animals and plants on exposed shorelines like wave exposed beaches are not of conservation importance, there is not a great deal of concern about the importance of oil on them. These types of shores have high self cleaning potential and oil is not likely to remain on the shore for long.

6) Sand: The grain sizes vary from $0.1 \mathrm{~mm}$ to $2 \mathrm{~mm}$. Coarse sand beaches tend to be more steeply and dry out 
at low water enabling some degree of penetration to occur especially with low viscosity oils, very often, sand beaches are regarded as an amenity resource and priority is given to cleaning them. Inter tidal sand flat on the other hand is often biologically productive and important for fisheries [17].

7) Mangrove Mud: They have grain size less than $0.1 \mathrm{~mm}$. Extensive deposits of mud are characteristic of low energy environment. Little penetration of the substrate by oil occurs because the sediments are usually water logged. Oil can persist in the surface over long period. If the spill coincides with a storm, oil will be incorporated in the sediments and persist indefinitely. Animal burrows and plant channels can also bring about oil penetration. The more dense nature of vegetation in mangrove leads to a high risk of oil being carried further into the mangrove [18]. Due to the fact that these natural receptors are wide open, they receive a wide range of pollutants, thereby acting as a reservoir of run-off and atmospheric pollutants (run-off/surface-water-atmospheric interaction).

\section{Companies Operating in the Area}

Nigeria's case is a classical case of mono-economy — an economy dominated by oil and its associated activities, which is the largest single contributor to the nation's gross domestic products. The scope of oil exploration and allied activities has been increasing over the years and thus its environmental consequences [19]. The exploration and exploitative activities are concentrated in the Niger Delta and they include: exploration (geographical investigation, geological survey, drilling), production/processing (platforms and tankfarms, gas flaring), Tank loading (locations and offshore), storage depots, exploitation (refinery, petrochemicals) and transportation (pipeline, tankers) [20]. Companies that operate in the Nigeria's crude oil region are faced with corrosive effect on their equipment. Acidic gases, water and precipitation wear away equipments for every stage of oil and gas production in the petroleum industry (extraction and refinery operation), in addition to transportation and storage suffer from corrosion threats. Petroleum industry deals with a variety of corrosive environments, and some of them are exclusively theirs [21]. Corrosion from petroleum production was given attention only about seven decades ago, due to the fact that increased level of acid components resulting from petroleum refining led to more losses. The presence of $\mathrm{H}_{2} \mathrm{~S}$ and $\mathrm{CO}_{2}$ gases in petroleum production, as gas levels rises, $\mathrm{pH}$ decreases and the corrosion rate rises, factors that affect acid gas corrosion include 1) the phase composition (water, oil and gas) present in the system, 2) chemical composition of the produced water, 3), temperature 4) flow and 5) the composition and the conditions of the metallic composition [22]. The transformation of $\mathrm{H}_{2} \mathrm{~S}$ and many sulphur oxides produced during the extraction and refining into concentrated sulphuric acid $\left(\mathrm{H}_{2} \mathrm{SO}_{4}\right)$ is of serious concern in oil and gas industry. Carbon dioxide dissolved in water forms carbonic acid $\left(\mathrm{H}_{2} \mathrm{CO}_{3}\right)$ which reduces $\mathrm{pH}$ [23]. Although it is not as corrosive as oxygen, it leads to corrosion through the formation of pits. Water present in crude oils also works as an electrolyte causing corrosion; attempt on their removal has proved difficult. It also hydrolyzes other compounds such as chloride which causes acidity to rise [24]. Hydrogen sulphide, mercaptans and other compounds that contain sulphur are present in many crude products processed in petroleum and gas refineries. $\mathrm{H}_{2} \mathrm{~S}$ stimulates and accelerates corrosion, leading to loss of plasticity and cracks in steel [25]. When $\mathrm{H}_{2} \mathrm{~S}$ is dissolved in water, it contributes to a reduction of $\mathrm{pH}$, but when $\mathrm{H}_{2} \mathrm{~S}$ and $\mathrm{O}_{2}$ occur together, the acid is oxidized slowly with water formation and elemental sulphur, which increases the corrosiveness of the medium [26]. Oil deposits in the sea/ocean has serious problem of aging (a limiting factor for any structure) and corrosion is one of its most severe features but corrosion in marine environment is complex since other environmental factors, the material and the high salinity significantly affects the structures. Petroleum exploration and exploitation usually take place in an ecological environment where geological conditions favours the accumulation of organic materials that eventually forms the source of crude oil, the deleterious effect of pollution can be measured in terms of the harm done to organisms within the ecosystem, the hazards caused to human health, hindrance to marine activities and impairment of water quality. One of the most dangerous activities associated with oil exploration and exploitation is the gas flaring. Gas flaring gives rise to emissions into the atmosphere of oxides of Nitrogen $\left(\mathrm{NO}_{\mathrm{x}}\right)$, oxides of sulphur $\left(\mathrm{SO}_{\mathrm{x}}\right)$ and oxides of carbon $\left(\mathrm{CO}_{\mathrm{x}}\right)$, including particulate ash. These gaseous pollutants are the major acid pre-cursor gases which fall as acidic rain, dew, fog or smog.

\section{Acid Rain}

Rain water is essential free of mineral solutes but slightly acidic due to presence of dissolved carbon dioxide or more highly acidic due to acid rain forming constituents. Acid rain refers to the deposition of wet (rain, snow, 
sleet, fog, cloudy water, and dew) and dry (acidifying particles and gases) acidic components. "Clean” or unpolluted rain has an acidic $\mathrm{pH}$, but usually no lower than 5.7, because carbon dioxide and water in the air react together to form carbonic acid, a weak acid according to the equation;

$$
\mathrm{H}_{2} \mathrm{O}_{(\mathrm{l})}+\mathrm{CO}_{2(\mathrm{~g})} \rightleftharpoons \mathrm{H}_{2} \mathrm{CO}_{3(\mathrm{aq})}
$$

Carbonic acid then can ionize in water forming low concentrations of hydronium and bicarbonate ions.

$$
\mathrm{H}_{2} \mathrm{O}_{(\mathrm{l})}+\mathrm{H}_{2} \mathrm{CO}_{3 \text { (aq) }} \rightleftharpoons \mathrm{HCO}_{3 \text { (aq) }}^{-}+\mathrm{H}_{3} \mathrm{O}_{(\text {aq) }}
$$

However, unpolluted rain can also contain other chemicals which affect its $\mathrm{pH}$. A common example is nitric acid produced by electric discharge in the atmosphere such as lightning [27]. Acid deposition as an environmental issue would include additional acids to $\mathrm{H}_{2} \mathrm{CO}_{3}$. Particulates, gases and aerosol in the atmosphere are commonly regarded as determinants of wet deposition chemistry. Anthropogenic emissions can be oxidized to produce carbon, sulphur and nitrogen compounds in the atmosphere [28], they are balanced stoichiometrically by a net production of hydrogen ion $\left(\mathrm{H}^{+}\right)$. Gaseous sulfuric and nitric acids are partially neutralized by gaseous $\mathrm{NH}_{3}$ to form $\mathrm{NH}_{4} \mathrm{NO}_{3}$ and $\left(\mathrm{NH}_{4}\right)_{2} \mathrm{SO}_{4}$, both common components of rainfall influenced by anthropogenic sources. $\mathrm{NH}_{3}$ the most basic specie in the atmosphere results from biodegradation of nitrogen-containing biological matter and bacterial reduction of nitrate. It is the only water-soluble base in significant quantity dissolved in atmospheric water droplets which plays a strong role in neutralizing atmospheric acids.

$$
\begin{gathered}
\mathrm{NH}_{3 \text { (aq) }}+\mathrm{HNO}_{3 \text { (aq) }} \rightarrow \mathrm{NH}_{4} \mathrm{NO}_{3 \text { (aq) }} \\
\mathrm{NH}_{3 \text { (aq) }}+\mathrm{H}_{2} \mathrm{SO}_{4 \text { (aq) }} \rightarrow \mathrm{NH}_{4} \mathrm{HSO}_{4 \text { (aq) }}
\end{gathered}
$$

The reaction simply produces three effects: 1 ) they produce $\mathrm{NH}_{4}^{+}$as dissolved or solid salts in the atmosphere 2) they partly neutralize atmospheric acidic constituents and 3) they produce relatively corrosive ammonium salt [29].

Nitric and sulphuric acids are regarded as the sole contributors of nitrate and sulfate in precipitation [30], and these are assumed to be the major sources of acidity in precipitation influenced by combusted hydrocarbons [27]. The major acid precursor gases $\left(\mathrm{SO}_{\mathrm{x}}\right.$ and $\mathrm{NO}_{\mathrm{x}}$ ) that cause acid rain in Niger Delta region of Nigeria are product of hydrocarbon combustion (gas flaring, volatile gases from oil spills and crude oil refining). Other economic activities in the area that can synergize acidic precipitation also abound. Oxides of nitrogen $\left(\mathrm{NO}_{\mathrm{x}}\right)$ are by-prod- ucts of firing processes of extremely high temperatures (automobiles, utility plant(s) and in chemical industries (fertilizer production, aluminum smelting). Natural processes such as bacterial action in soils, forest fires, and lightening can contribute significantly to the high value of this acid-forming gas in the atmosphere [7] [8]. Sulphur dioxide $\left(\mathrm{SO}_{2}\right)$ can be produced by iron and steel production, smelting of metal sulphate ore, plankton, and rotten vegetation: all these are common features in the Niger Delta region of Nigeria.

Combustion of fuels produces sulphur dioxide and nitric oxides. They are converted into sulphuric and nitric acids [31].

In the gas phase, sulphur dioxide is oxidized by reaction with the hydroxyl radical in rain through an intermolecular reaction [32].

$$
\mathrm{SO}_{2}+\mathrm{OH}^{-} \rightarrow \mathrm{HOSO}_{2}
$$

This is followed by:

$$
\mathrm{HOSO}_{2}+\mathrm{O}_{2} \rightarrow \mathrm{HO}_{2}+\mathrm{SO}_{3}
$$

In the presence of water, sulphur trioxide $\left(\mathrm{SO}_{3}\right)$ is converted rapidly to sulphuric acid

$$
\mathrm{SO}_{3(\mathrm{~g})}+\mathrm{H}_{2} \mathrm{O}_{(\mathrm{l})} \rightarrow \mathrm{H}_{2} \mathrm{SO}_{4(\mathrm{aq})}
$$

Nitrogen dioxide reacts with $\mathrm{OH}$ to form nitric acids

$$
\mathrm{NO}_{2}+\mathrm{OH}^{-} \rightarrow \mathrm{HNO}_{3}
$$

When clouds are present, the loss rate of $\mathrm{SO}_{2}$ is faster than can be explained by gas phase chemistry alone. This is due to reactions in the liquid water droplets. Hydrolysis is important in this respect. 
Sulphur dioxide dissolves in water and then hydrolyses in a series of equilibrium reactions:

$$
\begin{gathered}
\mathrm{SO}_{2(\mathrm{~g})}+\mathrm{H}_{2} \mathrm{O} \rightleftharpoons \mathrm{SO}_{2} \cdot \mathrm{H}_{2} \mathrm{O} \\
\mathrm{SO}_{2} \cdot \mathrm{H}_{2} \mathrm{O} \rightleftharpoons \mathrm{H}^{+}+\mathrm{HSO}_{3}^{-} \\
\mathrm{HSO}_{3}^{-} \rightleftharpoons \mathrm{H}^{+}+\mathrm{SO}_{3}^{2-}
\end{gathered}
$$

There are a large number of aqueous reactions that oxidize sulphur from sulphur 4) to sulphur 5) leading to the formation of sulphuric acid. The most important oxidation reactions are with ozone, hydrogen peroxide and oxygen, reactions with oxygen being catalysed by iron and manganese in the cloud [32].

Atmospheric reactions that lead to acid precipitation can take place in gas or aqueous phases. In gas phase, photolysis is important in the day time. The main oxidant for $\mathrm{SO}_{2}$ conversion to sulphuric acid is hydroxyl radical $\left(\mathrm{OH}^{-}\right)$, represented as:

$$
\begin{gathered}
\mathrm{SO}_{2}+\mathrm{OH}^{-} \rightleftharpoons \mathrm{HOSO}_{2} \\
\mathrm{O}_{2}+\mathrm{HOSO}_{2} \leftrightarrow \mathrm{HO}_{2}+\mathrm{SO}_{3} \\
\mathrm{SO}_{3}+\mathrm{H}_{2} \mathrm{O} \leftrightarrow \mathrm{H}_{2} \mathrm{SO}_{4}
\end{gathered}
$$

Diurnal variation in $\mathrm{OH}$ makes the above less important at night. Hydrogen peroxide is the principal oxidant in the aqueous phase, such as

$$
\begin{gathered}
\mathrm{SO}_{2}+\mathrm{H}_{2} \mathrm{O} \leftrightarrow \mathrm{H}^{+}+\mathrm{HSO}_{3}^{-} \\
\mathrm{HSO}_{3}^{-}+\mathrm{H}_{2} \mathrm{O}_{2} \leftrightarrow \mathrm{A}^{-}+\mathrm{H}_{2} \mathrm{O} \\
\mathrm{A}^{-}+\mathrm{H}^{+} \leftrightarrow \mathrm{H}_{2} \mathrm{SO}_{4}
\end{gathered}
$$

where $\mathrm{A}^{-}$is intermediate species [33]. Gas phase oxidation of nitrogen oxides to nitric acid is important in the daytime, with hydroxyl radical as principal oxidants and proceeds as

$$
\begin{gathered}
\mathrm{NO}_{2} \leftrightarrow \mathrm{NO}+\mathrm{O}^{-} \\
\mathrm{NO}+\mathrm{O}_{3} \leftrightarrow \mathrm{NO}_{2}+\mathrm{O}_{2} \\
\mathrm{NO}+\mathrm{OH}+\mathrm{M} \leftrightarrow \mathrm{HNO}_{2} \\
\mathrm{NO}_{2}+\mathrm{OH}+\mathrm{M} \leftrightarrow \mathrm{HNO}_{3}
\end{gathered}
$$

where $\mathrm{M}$ is any third body that can absorb energy: namely $\mathrm{N}_{2}$ or $\mathrm{O}_{2}$. At night any ozone present would oxidize $\mathrm{NO}_{2}$ to the nitrate radical, which in reacting with $\mathrm{N}_{2} \mathrm{O}$, would yield $\mathrm{NO}_{5}$ and ultimately nitric acid [33]. With an average $\mathrm{pH}$ of 4.86 and 5.23 of rain water from Port-Harcourt and 5.22 and 4.77 of rain water from Warri (two major crude oil producing cities in Niger Delta) in 2005 and 2006 respectively, the area experiences regular acidic precipitation. Due to the fact that our initial publications [7] [8], generated panic and varied reaction from the Nigeria populace, we embarked on twelve (12) years study and documentation of $\mathrm{pH}$ level and other parameters of rain water samples from Niger Delta region of Nigeria; our ten (10) years data (though yet unpublished) is consistent with our previous manuscript, this should be of serious concern to the Nigerian policy makers and oil company operators.

\subsection{Impact on Soil}

The effect of acid rain on soil depends on the behavior of ions in the soil [34]. Acidic precipitation dissolves and washes away soil nutrients (Organic matrix). Dissolved mineral matter in soil is largely present as ions. Important and prominent cations include $\mathrm{H}^{+}, \mathrm{K}^{+}, \mathrm{Ca}^{2+}, \mathrm{Mg}^{2+}$ and $\mathrm{Na}^{+}$etc., anions that may be present are $\mathrm{HCO}_{3}^{-}$, $\mathrm{SO}_{4}^{2-}, \mathrm{Cl}^{-}, \mathrm{CO}_{3}^{2-}$ and $\mathrm{F}^{-}$. Cation exchange in soil is a mechanism by which potassium, calcium, magnesium and other essential trace-level metals are available to plant, they are very important to the welfare of green plants and may be leached out and become unavailable to plants as nutrients. When nutrient ions are taken up by plant roots, hydrogen ions will be exchanged for the metal ions. This coupled with leaching of $\mathrm{Ca}^{2+}, \mathrm{Mg}^{2+}$ etc from soil by 
acidic water makes the soil to be acidic [29]. Agricultural and man's friendly fauna, earthworms and organism with very sensitive skin are destroyed. Toxic cations such as $\mathrm{Hg}^{2+}, \mathrm{Cd}^{2+}, \mathrm{Pb}^{2+}, \mathrm{Al}^{3+}$ etc, where they exist are demobilized into aquatic ecosystem where they bioconcentrate in lugworms, barnacles, algae and other planktonic and benthic organism enroute to food web. Loosened soil matrix may be susceptible to erosion. Soil may neutralize some or all of the acidity of rain water because of buffering capacity. Buffering capacity is the main reason why impact of acid rain is prominent in some soil and minimal or none existence in some and the buffering capacity depends mainly on the underlying bedrock and the human use and management of the soil [34], since acid rain is a regular occurrence in Niger Delta due to intense oil exploration and exploitation, a net negative effect of acid rain in the area is most likely. Acid rain can also increase the weathering of silicate minerals in soils. This results in loss of mineral structure and possibly reduced fertility. A possible chemical reaction involving silicates is the following:

$$
2 \mathrm{KAlSi}_{3} \mathrm{O}_{8}+2 \mathrm{H}^{+}+9 \mathrm{H}_{2} \mathrm{O}=\mathrm{Al}_{2} \mathrm{Si}_{2} \mathrm{O}_{5}(\mathrm{OH})_{4}+2 \mathrm{~K}^{+}+4 \mathrm{H}_{4} \mathrm{SiO}_{4}
$$

When soil pH dips to between 4.0 and 5.0: aluminium ions, which are normally present in an insoluble nontoxic form of aluminium silicates, are dissolved into water and become toxic to plants. Aluminium ions cause a stunting of the root growth and prevent the uptake of calcium, phosphorus and other nutrients [34] [35].

Hence, biology and chemistry of can be seriously damaged by acid rain. Some microbes are unable to tolerate changes to low $\mathrm{pH}$ and are killed [36]. The enzymes of these microbes are denatured by the acid. The hydronium ions of acid rain also mobilize toxins such as aluminium, and leach away essential nutrients and mineral such as magnesium.

$$
2 \mathrm{H}^{+}{ }_{\text {(aq) }}+\mathrm{Mg}^{2+}{ }_{\text {(clay) }} \rightleftharpoons 2 \mathrm{H}^{+}{ }_{\text {(clay) }}+\mathrm{Mg}^{2+}{ }_{\text {(aq) }}
$$

Soil chemistry can be drastically changed, base cations, such as calcium and magnesium, are leached by acid rain thereby affecting sensitive species, such as sugar maple (Acer saccharum) [37] [38].

\subsection{Impact on Natural Receptors}

Natural receptors (surface waters) of Nigeria in Niger Delta and indeed elsewhere are wide open, they act as reservoir to both atmospheric and land pollutants. Floods (run off) from soil that has received acidic precipitation carry various organic and inorganic chemical contaminants into surface water where they alter the water chemistry of the system especially the $\mathrm{pH}$. The $\mathrm{pH}$ of natural receptors may not be altered much because of the buffering action of metals and salts from floods (run-off) and salt water (with metal) intrusion from the ocean. In our previous work, the $\mathrm{pH}$ of most surface water in the Niger Delta were slightly more acidic in dry season than during the rainy season [39], this is indicative of the fact that dry acidic aerosols predominate in dry season. The reason is because in wet season, there is frequent rain and having sufficient volume of rain water, this gives a high opportunity for $\mathrm{SO}_{\mathrm{x}}$ to be dissolved as bisulphate $\left(\mathrm{HSO}_{3}^{-}\right)$and $\mathrm{H}^{+}$. Bisulphate is then oxidized continuously to $\mathrm{SO}_{4}^{2-}$ and more $\mathrm{H}^{+}$[40]. In a field study into $\mathrm{SO}_{2}$ and $\mathrm{NO}_{2}$ oxidization to $\mathrm{SO}_{4}^{2-}$ and $\mathrm{NO}_{3}^{-}$respectively, it was concluded that, while droplet-phase reactions are important for $\mathrm{SO}_{2}$ oxidization, gas-phase reactions are predominant for oxidation of $\mathrm{NO}_{2}$ [41].

It means that during the wet season, $\mathrm{SO}_{4}^{2-}$ is a major specie causing acidity in rainwater whereas during the dry season $\mathrm{NO}_{3}^{-}$plays a major role. The reason is that in dry season, both $\mathrm{SO}_{\mathrm{x}}$ and $\mathrm{NO}_{\mathrm{x}}$ deposit to the ground as dry deposition with different deposit rates, due to the fact that $\mathrm{NO}_{\mathrm{x}}$ having relatively higher residence time in the air than S0x, dry deposition of $\mathrm{NO}_{\mathrm{x}}$ is slower. This gives a higher opportunity for $\mathrm{NO}_{\mathrm{x}}$ remaining in the air to play a major role as a precursor causing acidity of rainwater during dry season [42].

The $\mathrm{pH}$ of underground water: shallow (hand dug) well and borehole (deep drilled well) water in Niger Delta region is significantly more acidic than that of surface water [43], this is because surface water is subject to buffering action. Increased metal levels of a given water body may be affected by increase in salinity, decrease in redox potential and decrease in $\mathrm{pH}$. Elevated salt concentrations create increased competition between cations and metals for binding sites; this will drive the metals off into the overlying water. This is the case in the estuaries because of fluctuating river flow inputs as seen in the Niger Delta area of Nigeria. Our previous work in the region has shown that the surface waters were contained with toxic cations such as $\mathrm{Pb}^{2+}, \mathrm{Cd}^{2+}, \mathrm{Zn}^{2+}, \mathrm{Mn}^{2+} \mathrm{Fe}^{2+}$ etc (Tables not shown) in values above US EPA MCL and therefore portends serious health hazards, the reason is due to the fact that it lacks alkalinity and acidic rain water aggressively breakdown some kinds of mineral 
matter, therefore surface water has higher concentrations of dissolved inorganic solids than rain water [7] [8] [39] [43] [44]. A low pH increases the competition between metal and hydrogen ions $\left(\mathrm{H}^{+}\right)$for binding sites. This low $\mathrm{pH}$ may also dissolve metal carbonate complex, increases the solubility and releasing free metal ions into the water column [45]. Increased salinity of the natural receptors led to higher levels of the toxic metals than $\mathrm{pH}$ [39]. Salinity of the water bodies of Niger Delta comes from three (3) routes, namely; intrusion of sea water, flood (run-off) from adjacent land mass which have received acidic precipitation and then recipient of acid rain itself by the surface water, this occurs when hydrogen ion $\left(\mathrm{H}^{+}\right)$in $\mathrm{H}_{2} \mathrm{SO}_{4}$ and $\mathrm{HNO}_{3}$ is replaced by metal ion (e.g. $\mathrm{K}^{+}$, $\mathrm{Na}^{+}$, replacing $\mathrm{H}^{+}$to form $\mathrm{K}_{2} \mathrm{SO}_{4}, \mathrm{KNO}_{3}, \mathrm{Na}_{2} \mathrm{SO}_{4}$ and $\mathrm{NaNO}_{3}$ ). Green algae and many forms of bacteria which are essential to aquatic life/system are killed due to acidity. Feeding of fish larvae are affected at pH below 6.0 and above 8.4 while some adults are unaffected at $\mathrm{pH}$ above 9.0 but the larval stages are appropriate at 8.5 [46]. Several species show reduced calcification as the $\mathrm{pH}$ is reduced towards 6.0 [4]. On personal interaction during our sampling expedition for a previous manuscript [43], local fishermen complained of reduced fish catches; this may partly be because planktons, fresh water shrimp, snails, mussels, lugworms, barnacles, etc on which fish feed are most affected by acidification [47]. Fish such as minnows, salmon and roach are equally threatened. Roe and Fry (eggs and young) of the fish are the worst affected. The acidification can also cause deformity of young fish and may prevent eggs from hatching properly, this directly affect fish eating birds and animals [48], with a pH of 5.22, 5.32 and 5.53 of surface waters of Orash River, Ughewhe Stream and Egbo Stream, it show that natural receptors (surface water) of the region receives acidic precipitation but most have good buffering capacity in comparison with the underground water of the area, other anionic species that may contribute to both acidic precipitation and buffering capacity of surface waters include fluoride $\left(\mathrm{F}^{-}\right)$, chloride $\left(\mathrm{Cl}^{-}\right)$and phosphate $\mathrm{PO}_{4}^{3-}$, while the anions contribute to acidity their salt induces buffering action.

Cations can abstract $\mathrm{H}^{+}$from acidic species or gaseous sulphuric and nitric acids-both common components of rainfall and replaced by metals such as $\mathrm{Zn}, \mathrm{K}, \mathrm{Mg}$ etc or can be partially neutralized by gaseous $\mathrm{NH}_{3}$ to form $\mathrm{NH}_{3} \mathrm{NO}_{3}$ and $\left(\mathrm{NH}_{4}\right)_{2} \mathrm{SO}_{4}$, these can cause nutrient enrichment of Niger Delta natural receptors, which already is a proven case in the area as our study authenticates [49]. Combination of nitrate, sulphate and phosphate are major causes of eutrophication in surface waters and natural receptors in the area can be said to be more fertile than adjacent landmass. Water transportation has been highly hindered by excessive growth of water hyacinth (Eichornia crassipes) and algal blooms which has clogged the Niger Delta water ways (natural receptors), this is because in well-oxygenated waters, these anions are taken up by aquatic plant, algae and bacteria and used for growth. In stagnant waters with very little dissolved oxygen certain types of bacteria, such as nitrosomonas and nitrobacter species convert nitrate to nitrite $\left(\mathrm{NO}_{2}^{-}\right)$. Nitrite values of surface water in Niger Delta from previous study were minimal but some were in health risk index value [39].

\section{Public Health Impact of Acid Rain}

The precursors of acid rain-sulphur dioxide $\left(\mathrm{SO}_{2}\right)$ and nitrogen oxides $\left(\mathrm{NO}_{\mathrm{x}}\right)$-do impair human health. These gases interact in the atmosphere to form fine particles that can be transported long distances by winds and inhaled deep in people's lungs. Fine particles can also penetrate indoors. Several scientific studies have identified a link between elevated levels of fine particles and increased illness and premature death from heart and lung disorders, such as asthma and bronchitis. $\mathrm{NO}_{\mathrm{x}}$ emissions, particularly, react with volatile organic compounds to form ozone. Ozone impacts on human health and include a number of morbidity and mortality risks associated with lung inflammation, including asthma and emphysema. However, the particulates responsible for acid rain (sulphur dioxide and nitrogen oxides) do have an adverse effect. Increased amounts of fine particulate matter in the air do contribute to heart and lung problems including asthma and bronchitis. Low levels of $\mathrm{SO}_{2}$ in air triggers some negative health effects which is primarily upon the respiratory tract, producing irritation and difficulty inbreathing, this is more pronounced in people with respiratory weaknesses and sensitized asthmatics, it also causes mucus secretion and eventually death at levels about 500 ppm but has not harmful to laboratory animals at 5 ppm [29]. N0 is less toxic and less active than $\mathrm{NO}_{2}$ but like carbon monoxide and nitrite, NO attaches to haemoglobin and reduces oxygen distribution to cells but in polluted environment, the concentration of NO is less than that of $\mathrm{CO}$ so the effect on haemoglobin is far less. Acute exposure to $\mathrm{NO}_{2}$ is quite harmful to human health, less than one hour exposure to 50 - 100 ppm of $\mathrm{NO}_{2}$ causes lung tissue inflammation within 6 - 8 weeks. Exposure to 150 - 200 ppm of $\mathrm{NO}_{2}$ causes bronchitis fibrosa obliferans, which can be fatal within 3 - 5 weeks after exposure. Death results within 2 - 5 days on exposure to about 500 ppm [29]. Acid rain does not directly 
affect human health. The acid in the rain water is too dilute to have direct adverse effects but for the severity of the effect of oil and gas exploration and exploitation, the acidity levels of rain water cannot be ignored and since Nigerians depends heavily on rain water or surface waters that has received acidic precipitation for drinking, cooking, laundry, and other domestic uses, especially in the Niger Delta area were potable water supply is lacking because of effect of oil and gas activities, serious health problems such as skin cancers and lesions may be linked to acid rain. Stomach ulcers could also occur, as consumption of acidic water can alter the $\mathrm{pH}$ of the stomach and leach the mucous membrane of the intestinal walls. In Canada, effect of acidic lake water on the eyes of human and laboratory animal were studied. In the study, the $\mathrm{pH}$ of one sample (A) was 4.6 and that of sample (B) 6.3. one eye of six healthy human volunteers and 21 normal rabbits was exposed repeatedly to sample A and the other eye to sample B, at the end of the study neither of the human eye resulted in any symptoms or signs, such as ocular congestion or corneal damage detectable by staining with fluorescein. In all of the rabbits but one neither sample resulted in conjunctival congestion, corneal damage, epithelial cells or leukocytes in the tears, or penetration of fluorescein into the aqueous humour [50].

\subsection{Effect of Acidic Anions}

Acidity of water is due to the interaction of anions with hydrogen ion $\left(\mathrm{H}^{+}\right)$, these anions include nitrate $\left(\mathrm{NO}_{3}^{-}\right)$, sulphate $\left(\mathrm{SO}_{4}^{2-}\right)$, phosphate $\left(\mathrm{PO}_{4}^{3-}\right)$ and chloride $\left(\mathrm{Cl}^{-}\right)$and at certain concentrations in water are associated with some problems.

1) Nitrate $\left(\mathrm{NO}_{3}^{-}\right)$

Nitrate in drinking water has long been regarded as a health threat for its ability to induce methemoglobinemia and this health outcome is the basis of the U.S. Environmental Protection Agency (EPA) maximum contaminant level [51]. Intake of nitrate from drinking water and dietary sources may cause increased exposure to N-niroso compounds through endogenous nitrosation [52]. Cos et al. (2004) [53] suggest that long term exposure to drinking water nitrate at levels below the maximum contaminant level (MCL) of nitrate nitrogen (10 mg/L) [54] is not associated with pancreatic cancer. In our previous work of acidic precipitation in Niger Delta area [8] and that of natural receptors [49], some of the nitrate levels could be of serious health effect. In general, the values of the parameters (nitrate, bicarbonate and sulphate) of rain water were less than that of surface water; this is because surface water is subject to buffering action. The work of Niagolova et al. (2005) [55], explored two hypotheses relating to the elevated concentration of nitrogen species in drinking water and the Balkan endemic Nephropathy (BEN) disease, this results established an exposure pathway between anthropogenic activity and drinking water supplies, suggesting that the causative agent for BEN could result from surface contamination. Although the role of nitrate in drinking water as a risk for cancer is controversial, high levels of nitrate in drinking water have been associated with increased mortality [56], and incidence of some cancers and lesions [57]. Spontaneous abortion, ectopic pregnancy [58]-[60], malignant lymphomas and soft tissues sarcomas [61] have been reported in the Niger Delta region of Nigeria. Children between the ages of 12 - 14 years drinking water containing nitrate, greater than $105 \mathrm{mg} / \mathrm{L}$ have been reported to exhibit delayed reactions to light and sound stimuli [62].

Pregnant women who drink nitrate-contaminated water may be at increased risk of having spontaneous abortion [63] or giving birth to infants with congenital malformations, especially of the central nervous system [64]. Turkdogan et al. (2003) [65] investigated nitrate and nitrite levels in some traditional foods and drinking water in Van, an endemic upper gastro intestinal (esophageal and gastric) cancer region of eastern Turkey. Their findings suggest that the influence of a traditional diet rich in nitrate and nitrite is significant in the development of upper gastrointestinal cancers in that region.

In animals, water and feed samples taken from five (5) different farms with a history of stillborn or blind calves were examined for nitrate in Burdur; Turkey, the results revealed nitrate and nitrite levels which ranged from 154 - $480 \mathrm{mg} / \mathrm{L}$ and 1.5 - $20 \mathrm{mg} / \mathrm{L}$ respectively. These levels can cause chronic poisoning. Levels of nitrate and nitrites in blood samples from the same cows and calves were found to be high while haemoglobin and methemogobin values were low and high respectively. Chronic nitrate toxicity in cow is a form of nitrate poisoning in which clinical signs of the disease are not observed, but can cause reduction in the rate of weight gain, lowered milk production, depressed appetite and a greater susceptibility to infection [66]. Marine invertebrates and fish exposed to nitrate may be smaller in size, have reduced maturity rate and lower reproductive success. In extremely high exposure levels, aquatic invertebrates and fish may die [67]. 
Early life stages of aquatic animals are more sensitive to nitrate than juvenile and adult animal, larval stages of amphibians are sensitive to nitrate exposure, nitrate can reduce the size and weight of frog tadpoles as they change into adult, this can hinder their ability to compete for food, mate or move away from predators [67]. The toxicity of nitrate results from its conversion to nitrite $\left(\mathrm{NO}_{2}^{-}\right)$which inhibit the function of haemoglobin (methglobinemia or blue baby syndrome). Toxicological effect of nitrite in human health is due to the fact that nitrite is approximately ten (10) times more toxic than nitrate [68]. When nitrite enters the blood stream; it interacts with the haemoglobin and forms methaemoglobin, a compound which reduces the blood's oxygen carrying capacity. As oxygen level reduces, it gives rise to signs of a disease condition in babies known as methaemoglobinemia, also known as "blue baby disease”. The next apparent symptom of methaemoglobinemia is the appearance of a bluish tone in the skin particularly around the eyes and mouth. If quickly discovered, the disease can be successfully treated using methylene blue injection, which changes methaemoglobin back to haemoglobin. However, if not treated, death occurs when $70 \%$ of the body's blood haemoglobin has been converted to methaemoglobin [69].

2) Sulphate $\left(\mathrm{SO}_{4}^{2-}\right)$

Sulphate is one of the least toxic anions of which the world health organization (WHO) does not have any recommended value for drinking water but catharsis, dehydration and gastro intestinal irritation have been linked to high sulphate concentration in drinking water. WHO therefore suggests urgent action by health authorities when sulphate in drinking water exceeds $500 \mathrm{mg} / \mathrm{L}$ [70]. High sulphate values of some surface water in the region may in part results from that added by acidic precipitation. Where the buffering capacity of the surface water is strong enough to decrease the acidity of the water, increased bacteria load, such as sulphate reducing bacteria follows.

3) Phosphate $\left(\mathrm{PO}_{4}^{3-}\right)$

Phosphate anions are dissolved but some are in combination with suspended particles and may contribute to turbidity. Phosphate anions are normally minimal in clean potable water. The relatively lower phosphate levels in our reported work [39] could be attributed to rapid uptake of nutrients by primary producers. Rast et al. (1989) [71] provided boundary ranges of phosphate- phosphorus as oligotrophic, mesotrophic, eutrophic and hypertropic aquatic system. According to them, the ranges are respectively $0.003-0.018,0.011-0.098 ; 0.016-0.386$ and 0.75 - 1.200 (mg/L). Different natural receptors in the Niger Delta region suit all the above categorization. Natural receptors such as ponds, salt marshes and mangrove swamps etc; which are sheltered and have a total phosphate-phosphorus level greater than $0.1 \mathrm{mg} / \mathrm{L}(>0.1 \mathrm{mg} / \mathrm{L})$ such as some entrophic and all hypertropic aquatic systems can over fertilize aquatic plants and cause stepped up cultural entrophication [72]. If this happens, the plants die more quickly than they are decomposed and the dead plant matter builds up together with sediments entering the water to fill the bed of the natural receptor(s) making it shallow [72]. Another common feature of such natural receptor is a low dissolved oxygen content which could have adverse negative effect in the existence of aquatic life like fishes.

4) Chloride ion $\left(\mathrm{Cl}^{-}\right)$

We had previously established high chloride ion $\left(\mathrm{Cl}^{-}\right)$in the surface water of the region. Although acidic precipitation is a major contributor to this effect, other factor contributor is intrusion of sea water [49]. This is because chloride make up much of the salt dissolved in the earth's ocean (sea water): about 1.9\% of the mass of sea water in chloride ions [69]. High chloride content in process waters may promote pipe corrosion; the region is replete with frequent oil pipeline breakdown due to corrosion. Although, chloride ions are essential to life [73], when the value is above $250 \mathrm{mg} / \mathrm{L}$ the water taste salty [74]. The alkalinity of some water is due only to the bicarbonates of calcium and magnesium and total alkalinity is identical with bicarbonate levels and reasonable values were reported in our previous study [49].

\subsection{Impact on Plants}

Adverse effects on forests and the other vegetation may be indirectly related to acid rain, or high concentration of gaseous precursors of acid rain. High altitude forests are especially vulnerable as they are often surrounded by clouds and fogs which are more acidic than rain.

Other plants can also be damaged by acid rain, but the effect on food crops is minimized by the application of lime and fertilizers to replace lost nutrients. When calcium is leached from the needles of red spruce, these trees become less cold tolerant and exhibit winter injury and even death [75] [76]. Acid precipitation can wear away 
the waxy protective coatings of leaves, damage them and reduce photosynthetic activities [7], nutrient loss from leaves (folain leaching), reduce rate of decomposition of leave litter, inhibit the formation of terminal buds, increase mortality of seedlings and heavy metal accumulation, destroy useful microorganisms that are symbiotic with tree roots and inhibit the nitrification of ammonium compounds [34]. In folian leaching, ammonia and nitrogen may land on the leaf, either wet or dry, and pass through the semi-permeable membrane in the leaf surface. It will then be incorporated into the leaf cells. A chemical interaction takes place in the leaves (cation exchange) and potassium, calcium, magnesium and sulphur are leached out and get washed away from the leaf surface. In reducing the rate of decomposition of the forest floor, soil organisms (including bacteria) have their respiration rate reduced. There is an increase in ammonia in the soil by the reduction in mobilization of nutrients (those that are usually released in decomposition) and there is a decrease in soil nitrate levels because the nitrification process is inhibited [34]. Although we are not aware of any study that has documented the effect of acidic deposition on the biota (plant) of Niger Delta and indeed that of Nigeria, literature evidence on the negative effect of acidic precipitation on biota exists; example, atmospheric deposition of acid ions has negatively affected the biota of European forests [77]. The negative effect ranged from loss of needles or leaves resulting in a more open canopy to the complete die-off of forest tree species; by this, the area may be unsuitable for forest birds owing to the loss of favourable nesting, roosting and foraging sites. In less buffered soils, vegetation is affected by acid deposition through reduction in growth rate and flowering ability of the plant. It makes plant more vulnerable to diseases, insects, drought and frosts [78]. A study of acid rain phenomenon in Cordoba province of Argentine revealed that the acidic effect seriously affected the forest wealth, causing a great defoliation of trees and shrubs, with a lower effect on crops [79]. Precursor gases $\left(\mathrm{SO}_{2}\right.$ and $\left.\mathrm{NO}_{2}\right)$ also adversely affect plants; extensive damage can be done to plants $\mathrm{NO}_{2}$, it causes leave spotting and breakdown of plant tissue and a decrease in rate of photosynthesis. Atmospheric $\mathrm{SO}_{2}$ is harmful tom plants, acute exposure kills leaf tissue (leaf necrosis) while chronic exposure causes chlorosis-bleaching/yellowing of green portions of the leaves. Its injury to plants increases with increasing relative humidity and during the day when the leave stomata are open. Long-term, low-level exposure to $\mathrm{SO}_{2}$ reduces the yields of grain crops, such as wheat or barley [29].

\subsection{Effect of Cation}

Acidic precipitation has contributed to the lowered $\mathrm{pH}$ and increased salinity of surface water of Niger Delta, this twin effect has affected the heavy metal levels $\left(\mathrm{Pb}^{2+}, \mathrm{Cd}^{2+}, \mathrm{Zn}^{2+}, \mathrm{Mn}^{2+}\right.$ etc) of the surface water in the area [39] [44]. Ingestion of these metals may pose great risks to human health. Lead $\left(\mathrm{pb}^{2+}\right)$ because of its size and charge similarity, can substitute for calcium and be included in bone. At higher levels of calcium, lead in bone is replaced and the free lead in the body system may cause nephrotoxicity, neurotoxicity and hypertension. The ability of $\mathrm{pb}^{2+}$ to undergo metathesis reactions with $\mathrm{Zn}^{2+}$ and $\mathrm{Ca}^{2+}$ methalloproteins resulting in loss of metabolic function continues to be a primary hypothesis underlying the detrimental effects of lead exposure [80]. Cadmium may interfere with the methallothionein's ability to regulate Zinc and Copper levels in the body. Methallothionein (a protein) binds to excess essential metals to render them unavailable. When cadmium induces methallothionein activity, it binds to copper and zinc, thereby disrupting the homeostasis level [81]; under long term environmental exposure, the effects include disturbance in the resorption in the proximal tubules, lung diseases and the skeletal system disorders [82]. Manganese exposure involves both psychiatric symptoms and Parkinsonism features [83]. Greek adults have experienced subclinical neurologic effects through drinking water with elevated levels of manganese [84] and decreased intellectual function in pediatric population in Araihazar, Bangladesh [85]. Manganese in drinking water has little effect on adult population but very detrimental effect on embryos and neonates [86].

Nickel-ion-hypothesis suggests that $\mathrm{Ni}^{2+}$ is the active agent in $\mathrm{Ni}$ toxicity and that its intracellular concentration is a major toxic determinant, irrespective of the Ni compound to which an individual is exposed [87]. Many chromium compounds are carcinogenic, long term exposure can cause kidney, liver and nerve tissue damage [88]. Haemochromatisis is a genetic effect caused by high iron content or in severe cases can cause secondary hemochromatisis and thalassaemia [88]. Iron is contained in most food and blood supplement and therefore a blood builder, it is the most important transition element biologically, 70\% of the body's iron content is found as hemoglobin, the red pigment in erythrocytes; most of the iron is stored in the body as ferretin [89]. Despite the many good function of iron in man, plant and bacteria, [oxygen storage in muscle, electron transfer in plant and bacteria (ferredoxins) and electron carrier in plants, animal and bacteria (cytochromes) [89]; excessive intake of 
iron can cause a disorder with serious health problems or premature death [90]. Iron toxicity may cause liver, heart, endocrine glands damage and poor growth [91] [92]. Vomiting and diarrhea are the major and initial signs of zinc toxicity while copper, though an essential element but in excess can be detrimental to health. Apart from exposure through natural receptors, consumption of fish that has accumulated these metals from the natural receptors of the Niger Delta are a major route of exposure. Our previous work on metal levels in muscles and different parts of some fish species in surface waters of Nigeria's Niger Delta [93] [94], shows that the metals are more in concentration in the fish species than the surface water samples.

\section{Conclusion}

Therefore we conclude that acid rain and acidic deposition on natural receptors, resulting from oil and gas exploration and exploitation in the Niger Delta region, have the capacity to synergize both negative environmental and public health impact. Plants and soil are also negatively affected, including marble works, metal works, monuments and bridges.

\section{References}

[1] Shirazi, M.M.A., Kargari, A. and Shirazi, M.J.A. (2012) Direct Contact Membrane Distillation for Seawater Desalination. Desalination and Water Treatment, 49, 368-375. http://dx.doi.org/10.1080/19443994.2012.719466

[2] Shirazi, M.M.A., Kargari, A., Tabatabaei, M., Mostafaeri, B., Akia, M., Barkhi, M. and Shirazi, M.J.A. (2013) Acceleration of Biodiesel-Glycerol Decantation through NaCl-Assissted Gravitational Settling: A Strategy to Economize Biodiesel Production. Bioresource Technology, 134, 401-406. http://dx.doi.org/10.1016/j.biortech.2013.02.026

[3] Speight, J.G. (2006) The Chemistry and Technology of Petroleum. 4th Edition, CRC Press, Wyoming.

[4] Speight, J.G. (2002) Handbook of Petroleum Products Analysis. John Wiley and Sons, Inc., Hoboken.

[5] Schwartz, J. (2004) Air Pollution and Children's Health. Pediatrics, 113, 1037-1043.

[6] Maisonet, M., Correa, A., Misra, D. and Juakkola, J.J.K. (2004) A Review of the Literature on the Effects of Ambient Air Pollution on Fetal Growth. Environmental Research, 95, 106-115. http://dx.doi.org/10.1016/j.envres.2004.01.001

[7] Nduka, J.K.C., Orisakwe, O.E., Ezenweke, L.O., Ezenwa, T.E., Chendo, M.N. and Ezeabasili, N.G.(2008) Acid Rain Phenomenon in Niger Delta Region of Nigeria: Economic, Biodiversity and Public Health Concern. The Scientific World Journal, 8, 811-818. http://dx.doi.org/10.1100/tsw.2008.47

[8] Nduka, J.K. and Orisakwe, O.E. (2010) Precipitation Chemistry on Occurrence of acid Rain over the Oil Producing Niger Delta Region of Nigeria. The Scientific World Journal, 10, 528-534. http://dx.doi.org/10.1100/tsw.2010.61

[9] Reijers, T.J.A., Petters, S.W. and Nwajide, C.S. (1996) The Niger Delta Basin. In: Reijers, T.J.A., Ed., Selected Chapters on Geology, Sedimentary Geology and Stratigraphy in Nigeria, SPDC, Nigeria, 103-117.

[10] Awosike, L.F. (1995) Impact of Global Climate Change and Sea Level Rise on Coastal Resources and Energy Development in Nigeria. In: Umolu, J.C., Ed., Global Climate Change: Impact on Energy Development, DAMTECH Nigeria Limited, Nigeria, 76-89.

[11] Lambert-Aikhionbare, D.O., Bush, P.R. and Ibe, A.C. (1990) Integrated Geological and Geochemical Interpretation of Source Rock Studies in the Niger Delta. Journal of Mining and Geology, 26, 97-106.

[12] Abam, T.K.S. and Okagbue, P.I. (1997) The Cone Penetrometer and Soil Characterization in the Deltas. Journal of Mining and Geology, 33, 15-24

[13] Oteze, G.E. (1983) Ground Water and Ground Movement. In: Ola, S.A., Ed., Tropical Soils of Nigeria in Engineering Practice, A. A. Balkema Publishers, Rotterdam, 172-195.

[14] Amadi, P.A. (1986) Characteristics of Some Natural Waters from the Port-Harcourt Area of Rivers State, Nigeria. Unpublished MSc. Thesis, University of Ibadan, Ibadan, 98.

[15] National Atlas (1987) Atlas of the Federal Republic of Nigeria. Government Press, Lagos, 136.

[16] Olobaniyi, S.B. and Owoyemi, F.B. (2006) Characterization by Factor Analysis of the Chemical Facies of Ground Water in the Deltaic Plain Sands Aquifer of Warri Western Niger Delta. Nigeria African Journal of Science and Technology, 7, 73-81.

[17] SPDC (1997) Oil Chemical Spill Contingency Plan and Procedures. Bulletin, Nigeria.

[18] Nduka, J.K. (2000) Use of Solid Waste as Oil Spill Mop. Unpublished MSc Thesis, Pure and Industrial Chemistry Department, Nnamdi Azikiwe University, Awka, Nigeria.

[19] Adeyemi, O.T. (2004) Oil Exploration and Environmental Degradation: The Nigeria Experience. Environmental Informatics Archives, 2, 387-393. 
[20] Babalola, M.A. (1999) Impact of Oil on the Environment. Proceedings of Environmental Protection and the Petroleum Industry, UNILAG Consult.

[21] Frauches, C.S., DeAlbuqueque, M.A., Campos de Olibveira, M.C. and Echevarria, A. (2015) Corrosion and Anti-Corrosion Agents. In: Pant, K.K., Sinha, S., Bajpai, S. and Govil, J.N., Eds., Advances in Petroleum Engineering, Stadium Press LLC, USA, 752-768.

[22] Lyons, W.C. and Plisga, G.J. (2005) Standard Handbook of Petroleum and Natural Gas. 2nd Edition, Elsevier Inc., Massachusetts.

[23] Kinsella, Y.J., Tan, Y.J. and Bailey, S. (1998) Electrochemical Impedance Spectroscopy and Surface Characterization Techniques to Study Carbon Dioxide Corrosion Product Scales. Corrosion, 54, 835-842. http://dx.doi.org/10.5006/1.3284803

[24] Corrosipon and Petroleum (2008) Corrosion Engineering.co.cc. http://corrosion.Malaysiapetroleum.blogspot.com.br/2008/06/corrosion-in-petroleum-industry.html

[25] Lasebikan, B.A., Akinsanya, A.R., Deans, W.F. and Macphee, D.E. (2011) The Effect of Hydrogen Sulphide on Ammonium Bisulphate When Using an Oxygen Scavenger in Aqueous Solution. Corrosion Science, 53, 4014-4025. http://dx.doi.org/10.1016/j.corsci.2011.08.011

[26] Souza, F.S. and Spinelli, A. (2009) Caffeic Acid as a Green Corrosion Inhibitor for Mild Steel. Corrosion Science, 51, 642-649. http://dx.doi.org/10.1016/j.corsci.2008.12.013

[27] Likens, G.E., William, C., Miller, J.M. and Galloway, J.N. (1987) Chemistry of Precipitation from a Remote, Terrestrial Site in Australia. Journal of Geophysics Research, 92, 13299-13314. http://dx.doi.org/10.1029/JD092iD11p13299

[28] Cogbill, C.V. and Likens, G.E. (1974) Acid Precipitation in the Northeastern USA. Water Resources Res. Water Resources Research, 10, 1133-1137. http://dx.doi.org/10.1029/WR010i006p01133

[29] Bhatia, S.C. (2010) Environmental Chemistry. CBS Publishers \& Distributors Pvt. Ltd., New Delhi.

[30] Chan, W.H., Tang, A.J.S., Chung, D.W.S. and Reid, N.W. (1987) An Analysis of Precipitation Chemistry Measurements in Ontario. Environmental Science \& Technology, 21, 1219-1224. http://dx.doi.org/10.1021/es00165a010

[31] Clean Air Act, CAA (1998) Reduces Acid Rain in Eastern United States. Science Daily. 28 September.

[32] Seinfield, J.H. and Pandis, S.N. (1998) Atmospheric Chemistry and Physics-From Air Pollution to Climate Change. John Wiley and Sons Inc., Hoboken.

[33] Perhac, R.M. (1992) Acid Rain Encyclopedia of Physical Science and Technology. Vol. 1, Academic Press, London, 67-73.

[34] MacDaniel (2015). http://www.mcdaniel.edu/Biology/botf99/nutrition/acidrain.html.retrieved

[35] Ophard, C.E. (2003) Acid Rain Effects Soils. http://www/elmburst.edu/melim/uchembook/196soil.html

[36] Rodhe, H., Dentener, F. and Schulz, M. (2002) The Global Distribution of Acidifying Wet Deposition. Environmental Science \& Technology, 36, 4382-4388. http://dx.doi.org/10.1021/es020057g

[37] Likens, G.E., Driscoll, C.T., Buso, D.C., Mitchel, M.J., Lovett, G.M., Bailey, S.W., Siccana, T.G., Reiners, W.A. and Alewell, C. (2002) The Biogeochemistry of Sulfur at Habbard Brook. Biogeochemistry, 60, 235-316. http://dx.doi.org/10.1023/A:1020972100496

[38] Likens, G.E., Driscoll, C.T. and Buso, D. (1996) Long-Term Effects of Acid Rain: Response and Recovery of a Forest Ecosystem. Science, 272, 244-246. http://dx.doi.org/10.1126/science.272.5259.244

[39] Nduka, J.K. and Orisakwe, O.E. (2011) Water Quality Issues in the Niger Delta of Nigeria: A Look at Heavy Metal Levels and Some Physicochemical Properties. Environmental Science and Pollution Research, 18, 237-246. http://dx.doi.org/10.1007/s11356-010-0366-3

[40] Howells, G. (1995) Acid Rain and Acid Waters. 2nd Edition, Ellis Horwood, New York.

[41] Radojevic, M. (1992) $\mathrm{SO}_{2}$ and $\mathrm{NO}_{\mathrm{x}}$ Oxidation Mechanism in the Atmosphere. In: Radojevic, M. and Harrison, R.M., Eds., Atmospheric Acidity, Elsevier Applied Science, London.

[42] Panyakapo, M. and Onchnag, R. (2008) A Four-Year Investigation on Wet Deposition in Western Thailand. Journal of Environmental Sciences, 20, 441-448. http://dx.doi.org/10.1016/S1001-0742(08)62077-X

[43] Nduka, J.K., Orisakwe, O.E. (2009) Effect of Effluents from Warri Refinery and Petrochemical Company (WRPC) on Water and Soil Qualities of "Contiguous Host" and "Impacted on Communities" of Delta State, Nigeria. The Open Environmental Pollution and Toxicology Journal, 1, 11-17. http://dx.doi.org/10.2174/1876397900901010011

[44] Nduka, J.K.C. and Orisakwe, O.E. (2007) Heavy Metal Levels and Physico-Chemical Quality of Potable Water Supply in Warri, Nigeria. Annali di Chimica, 97, 867-874. http://dx.doi.org/10.1002/adic.200790071 
[45] Connell, D.W. and Miller, G.J. (1984) Chemistry and Ecotoxicology of Pollution. Wiley InterScience, New York.

[46] Wolff, E.W., Seager, J., Copper, V.A. and Orr, J. (1988) Proposed Environmental Quality Standards for List 11 Substances in Water. pH WRC Report TR, 259.

[47] Smith, A.D. and Roth, A.A. (1979) Effect of Carbon Dioxide Concentration on Calcification in the Red Coralline Alga Bossiella orbigniana. Marine Biology, 52, 217-225. http://dx.doi.org/10.1007/BF00398135

[48] Goyer, R.A., Bachman, J., Clarkson, T.W., Ferris, B.G., Graham, J., Mushak, R., Perl, D.P., Rall, D.P., Schlessinger, R., Sharp, W. and Wood, J.M. (1985) Potential Human Health Effects of Acid Rain: Report of a Workshop. Environmental Health Perspectives, 60, 355-368. http://dx.doi.org/10.1289/ehp.8560355

[49] Orisakwe, O.E. and Nduka, J.K. (2011) Assessment of Pollution Profiles of Some Surface Water in Niger Delta. Lambert Academic Publishers, Saarbrücken.

[50] Jefffs, D.N. (1980) Acid Rain and the Eye. Director Water Resources Branch, Ontario Ministry of Environment, Personal Communication.

[51] Bruning-Fann, C.S. and Kaneene, J.B. (1993) The Effects of Nitrate, Nitrite and N-Nitorso Compounds on Human Health: A Review. Veterinary and Human Toxicology, 35, 521-538.

[52] Mirvish, S.S. (1995) Role of N-Nitroso Compound (NOC) and N-Nitrosation in Etiology of Gastric, Esophageal, Nasopharyngeal and Bladder Cancer and Contribution to Cancer of Known Exposures to NOC. Cancer Letters, 93, 17-48. http://dx.doi.org/10.1016/0304-3835(95)03786-V

[53] Coss, A., Cantor, K.P., Reif, J.S., Luynch, C.F. and Ward, M. (2004) Pancreatic Cancer and Drinking Water and Dietary Source of Nitrate and Nitrite. American Journal of Epidemiology, 159, 693-701. http://dx.doi.org/10.1093/aje/kwh081

[54] World Health Organization (1985) 1985 Health Hazards from Nitrates in Drinking Water. World Health Organization (WHO), Geneva.

[55] Niagolova, N., McElmurry, S.P., Voice, T.C., Long, D.T., Petropoulos, E.A., Havezov, I., Chou, K. and Ganev, V. (2005) Nitrogen Species in Drinking Water Indicate Potential Exposure Pathway of Balkam Endemic Nephropaty. Environmental Pollution, 134, 229-237. http://dx.doi.org/10.1016/j.envpol.2004.08.003

[56] Cantor, K.P. (1997) Drinking Water and Cancer. Cancer Causes \& Control, 8, 293-308. http://dx.doi.org/10.1023/A:1018444902486

[57] Gulis, G., Czompolyova, M. and Cerhan, J.R. (2002) An Ecologic Study of Nitrate in Municipal Drinking Water and Cancer Incidence in Trnava District, Slovakia. Environmental Research, 88, 182-187. http://dx.doi.org/10.1006/enrs.2002.4331

[58] Gharoro, E.P. and Igbafe, A.A. (2002) Ectopic Pregnancy Revisited in Benin City, Nigeria: Analysis of 152 Cases. Acta Obstetricia et Gynecologica Scandinavica, 81, 1139-1143. http://dx.doi.org/10.1034/j.1600-0412.2002.811207.x

[59] Omoti, C.E. and Halim, N.K. (2005) Adult Lymphomas in Edo State Niger Delta Region of Nigeria Clinicopathological Profile of 205 Cases. Clinical \& Laboratory Haematology, 27, 302-306. http://dx.doi.org/10.1111/j.1365-2257.2005.00711.x

[60] Omoti, C.E. (2006) Socio-Demographic Factors of Adult Malignant Lymphomas in Benin City, Nigeria. Nigerian Postgraduate Medical Journal, 13, 256-260.

[61] Seleye-fubara, D., Nwosu, S.O. and Yellow, B.E. (2005) Soft Tissue Sarcomas in the Niger Delta Region of Nigeria (a Referral Hospital Study). Nigerian Journal of Medicine, 14, 188-194.

[62] Robillard, P.D., Sharpe, W.E. and Wistock, B.R. (2003) Nitrates in Drinking Water. Pennsylvania State University, Agricultural and Biological Engineering.

[63] Centre for Disease Control and Prevention, CDCP (1996) Spontaneous Abortions Possibly Related to Ingestion of Nitrated Contaminated Well Water-LaGrange Country, Indiana, 1991-1994. Morbidity and Mortality Weekly Report (MMWR), 45, 569-572.

[64] Croen, L.A., Todoroff, K. and Shaw, G.M. (2001) Maternal Exposure to Nitrate from Drinking Water and Diet and Risk for Neural Tube Defects. American Journal of Epidemiology, 153, 325-331. http://dx.doi.org/10.1093/aje/153.4.325

[65] Turkdogan, M.K., Testereci, H., Akman, N., Kahraman, T., Kara, K., Tuncer, I. and Uygan, I. (2003) Dietary Nitrate and Nitrite Levels in an Endemic Upper Gastrointestinal (Esophageal and Gastric) Cancer Region of Turkey. The Turkish Journal of Gastroenterology, 14, 50-53.

[66] Ozmen, O., Mor, F., Sahinduran, S. and Unsal, A. (2005) Pathological and Toxicological Investigations of Chronic Nitrate Poisoning in Cattle. Toxicology and Environmental Chemistry, 87, 99-106. http://dx.doi.org/10.1080/02772240400007104 
[67] Ohio State University (2008) Nitrates in Surface Water. Department of Horticulture and Crop Science, Ohio State University Extension, Columbus. http://ohioline.osu.edu/agffact/0204.htm/

[68] Schneider, N.R. (2012) Overview of Nitrate and Nitrite Poisoning. http://www.merckmaniuals.com/vet/toxicology/nitrate_and_nitrite_poisoning/overview_of_nitrate_and_nitrite_poisoni $\underline{\text { ng.html }}$

[69] Lenntech (2014) Hazardous Substances. http://www.lenntech.com/hazardous-substances/nitrite.htm

[70] Bertram, J. and Balance, R. (1996) A Practical Guide to the Design and Implementation of Fresh Water Quality Studies and Monitoring Programmes. Published on behalf of United Nations Environmental Programme (UNEP) and World Health Organization (WHO) E \& FN Spon publishers, 172-177, 192-196.

[71] Rast, W., Holland, M. and Rydings, S. (1989) Eutrophication Management Framework for the Policy Maker MAB Digest I UNESCO. Paris.

[72] Oran, B. (2015) Phosphate in the Environment. http://www.water_research.net/index.php/phosphates

[73] Duffus, J. (1996) Comments to editor, Chemistry International. News Magazine of International Union of Pure and Applied Chemistry (IUPAC), 18, 252-253.

[74] Hauser, B.A. (2011) Drinking Water Chemistry. A Laboratory Manual. Turbidity Herp II, Lewis Publishers, A CRC Press Company, Florida.

[75] Deltayes, D.H., Schaberg, P.G. and Strimbeck, G.R. (2001) Red Spruce Hardiness and Freezing Injury Susceptibility. In: Bigrass, F., Ed., Conifer Cold Hardiness, Kluwer Academic Publishers, 124-146.

[76] Lazarus, I.S., Schaberg, P.G., Hawley, G.J. and Deltays, D.H. (2006) Landscape-Scale Spatial Patterns of Winter Injury to Red Spruce Foliage in a Year of Heavy Region-Wide Injury. Canadian Journal of Forest Research, 36, $142-$ 152. http://dx.doi.org/10.1139/x05-236

[77] Flousck, J., Hudock, K. and von Blotzheim, U.N.G. (1996) In: Von Blotzheim, U.N.G., Ed., Handbuch der Vogel Mitteleuropas, Aula, Wischb aden, Germany, 11-30.

[78] Noweir, K.H., EI-Marakby, F.A., Zaki, G.R. and Ibrahim, A.K. (2008) Study of the Acidic Deposition Phenomenon over Alexandria City. The Journal of the Egyptian Public Health Association, 83, 147-164.

[79] Astolfi, E., Gotelli, C. and Higa, J. (1986) Industrial Ecotoxicology “Acid Rain”. Geographia Medica, 16, 1-10.

[80] Lewis, J.A. and Cohen, S.M. (2004) Addressing Lead Toxicity: Complexation of Lead(II) with Thiopyrone and Hydroxypyridinethione O,S Mixed Chelators. Inorganic Chemistry, 43, 6534- 6546. http://dx.doi.org/10.1021/ic0493696

[81] Kennish, M.J. (1992) Ecology of Estuaries: Anthropogenic Effects. Vol. 2, CRC Press, Boca Raton, 45-62.

[82] Jacubowski, M. (1997) Exposure to Chemical Factors in the Work Environment. In: Jacubowski, M., Ed., Biological Monitoring, Nofer Institute of Occupational Medicine, Lodz, 165-177.

[83] Dobson, A.W., Erickson, K.M. and Aschner, M. (2004) Management Neurotoxicity. Annals of the New York Academy of Sciences, 1012, 115-128. http://dx.doi.org/10.1196/annals.1306.009

[84] Kondakis, X.G., Makris, N., Leotsinidis, M., Prinou, M. and Papapetropoulos, T. (1989) Possible Health Effects of High Manganese Concentration in Drinking Water. Archives of Environmental Health: An International Journal, 44, 175-178. http://dx.doi.org/10.1080/00039896.1989.9935883

[85] Wasserman, G.A., Liu, X., Parvez, F., Ahsan, H., Levy, D., Factor-Litvak, P., Kline, J., van Geen, A., Slavkovich, V., Lolacono, N.J., Cheng, Z., Zheng, Y. and Graziano, J.H. (2006) Water Manganese Exposure and Children’s Intellectual Function in Araihazar, Bangladesh. Environmental Health Perspectives, 114, 124-129.

[86] Haffema, D., Factor-Litvak, P., Cheng, Z.Q., van Green, A. and Ahsan, H. (2007) Association between Manganese Exposure through Drinking Water and Infants Mortality in Bangladesh. Environmental Health Perspectives, 115, 1107-1112. http://dx.doi.org/10.1289/ehp.10051

[87] Neibor, E., Rostto, F.E. and Menon, C.R. (1988) Toxicology of Nickel Compounds. In: Siegel, H. and Siegel, A., Eds., Nickel and Its Role in Biology: Metal Ions in Biological Systems, Alfred Dedter, New York, 359-402.

[88] Praydot, P. (1999) Comprehensive Guide to the Hazardous Properties of Chemical Substance. 2nd Edition, John Wiley and Sons Inc., Canada, 614- 624.

[89] Lee, J.D. (1996) Concise Inorganic Chemistry. 5th Edition, Blackwell Science, London, 775-779.

[90] Olivieri, N.F. and Brittenham, G.M. (1997) Iron-Chelating Therapy and the Treatment of Thalassemia. Blood, 89, 739-761.

[91] Andrews, N.C. (1999) Disorders of Iron Metabolism. The New England Journal of Medicine, 341, 1986-1995. http://dx.doi.org/10.1056/NEJM199912233412607 
[92] Porter, J.B. (2001) Practical Management of Iron Overload. British Journal of Haematology, 115, 239-252. http://dx.doi.org/10.1046/j.1365-2141.2001.03195.x

[93] Nduka, J.K.C., Constance, E. and Obiakor, E. (2006) Selective Bioaccumulation of Metals by Different Parts of Some Fish Species from Crude Oil Polluted Water. Bulletin of Environmental Contamination and Toxicology, 77, 846-853. http://dx.doi.org/10.1007/s00128-006-1221-6

[94] Nduka, J.K., Orisakwe, O.E. and Okerulu, I.O. (2010) Heavy Metal Levels in Muscles of Some Fish Species from Aladja River; Warri, Nigeria: A Public Health Concern. Advances in Environmental Biology, 4, 125-130. 